\title{
PENGEMBANGAN LEMBAR KERJA SISWA (LKS) DENGAN PENDEKATAN INKUIRI TERBIMBING BERBASIS MOBILE LEARNING UNTUK MENGOPTIMALKAN KEMAMPUAN BERPIKIR KRITIS MATEMATIS
}

\author{
Rida Siti Halimatu Sadiyyah ${ }^{1}$, Mahmud Gustiana ${ }^{2}$, Satrio Damar Punuluh ${ }^{3}$, Rani Sugiarni ${ }^{4}$ \\ 1,2,3,4 Universitas Suryakancana \\ ridasadiyyah03@gmail.com \\ mahmudgustiana1998@gmail.com \\ ranisugiarni@gmail.com
}

Penerimaan : 17 Juni 2019

Diterima: 30 Juni 2019

\begin{abstract}
ABSTRAK
Rendahnya nilai matematika siswa yakni kurangnya kegiatan yang melatih keterampilan berpikir kritis siswa dalam memberikan latian soal atau Lembar Kerja Siswa. Selain itu pemilihan model pembelajaran yang kurang tepat dapat berdampak pula pada hasil belajar matematika. Tujuan dari penelitian ini yakni Penerapan pengembangan lembar kerja siswa dengan pendekatan inkuiri terbimbing berbasis mobile learning dapat mengoptimalkan kemampuan berpikir kritis matematis. Penelitian ini menggunakan metode pengembangan atau development research dengan metode ADDIE, adapun yang dikembangkan dalam penelitian ini adalah Lembar Kerja Siswa dengan Metode ADDIE berbasis Mobile Learning Untuk mengoptimalkan Kemampuan Berpikir Kritis Matematis. Subjek dalam penelitian ini kelas VII SMP Negeri 4 Campaka semester II tahun ajaran 2018/2019 pada materi Geometri. Prosedur penelitian yakni analisis, design, development, implementation dan evalution. Instrumen yang digunakan LKS, angket, dan tes kemampuan berpikir kritis. Berdasarkan hasil penelitian menunjukan bahwa pengembangan lembar kerja siswa dengan pendekatan inkuiri terbimbing berbasis mobile learning dari hasil penilain validator baik dan layak serta dapat mengoptimalkan kemampuan berpikir kritis matematis disertai sikap positif siswa.
\end{abstract}

Kata Kunci : Lembar Kerja Siswa, Berpikir Kritis, Inquiri, Mobile Learning.

\section{ABSTRACT}

The low mathematics value of students is the lack of activities that train students' critical thinking skills in giving questions or Student Worksheets. In addition, the selection of an inappropriate learning model can also have an impact on the learning outcomes of mathematics. The purpose of this study is that the application of developing student worksheets with a guided inquiry approach based on mobile learning can optimize mathematical thinking skills. This study uses development methods or development research with the ADDIE method, while the ones developed in this study are Student Worksheets with the ADDIE Method based on Mobile Learning to optimize Mathematical Critical Thinking Ability. Subjects in this study were class VII Campaka 4 Middle School second semester 2018/2019 in Geometry material. Research procedures namely analysis, design, development, implementation and evaluation. The instruments used were worksheets, questionnaires, and tests of critical thinking skills. Based on the results of research that shows the development of student worksheets using guided inquiry based on 
mobile learning from the results of the validator's assessment of good and proper and can support the ability to think mathematically improve the positive attitude of students.

Keywords: Student Worksheets, Critical Thinking, Inquiry, Mobile Learning.

\section{PENDAHULUAN}

Pada abad 21 ini, untuk menghadapi kemajuan jaman baik teknologi maupun ilmu pengetahuan dibutuhkan sumber daya manusia yang memiliki kemampuan berpikir kritis, oleh karena itu kemampuan berpikir kritis seseorang harus dilatih semenjak dini, peran pendidikan sangat penting untuk mencetak generasi muda berpola pikir kritis, karena pendidikan merupaka suatu lembaga yang berperan untuk menumbuh kembangkan potensi, eksistensi peserta didik yang memasyarakat, membudaya, dalam tatanan kehidupan yang berdimensi local, nasional dan global.

Dalam kurikulum 2013 sudah jelas bahwa keterampilan yang harus dimiliki siswa pada abad 21 ini salah satunya adalah 4C (Communication,Collaboration,Critical Thinking and Problem Solving, Creative and Innovation), jadi setiap siswa harus bisa berkomunikasi dengan baik, bekerjasama dengan team, berpikir kritis, bisa memecahkan suatu permasalahan, kreatif dan selalu berinovasi. Bisa disimpulkan bahwa kemampuan berpikir kritis siswa merupakan poin penting yang harus dimiliki dan terus dikembangkan.

Dengan kemampuan berpikir kritis seseorang akan menentukan / mempertimbangkan secara hati-hati dan sengaja apakah menerima, menolak atau menunda penerimaan suatu informasi, kemampuan berpikir siswa bisa ajarkan melalui pembelajaran matematika, khususnya pelajaran matematika dengan pemecaha masalah. Melalui pembelajaran siswa dilatih untuk menggunakan kemampuan berpikir kritis dalam setiap tahapan pemecahan masalah mulai dari, memahami masalah, merencanakan, pemecahan masalah, melaksanakan rencana pemecahan sampai pada mengevaluasi kembali pemecahan yang telah dilaksanakan.

Keterampilan berpikir kritis siswa bisa tumbuh dan berkembang jika menggunakan model pembelajaran yang tepat, model pendekatan inkuiri terbimbing merupakan salah satu model pembelajaran yang tepat, karena model pendekatan inkuiri terbimbing mencangkup tahapan-tahapan yang diinginkan dalam proses ningkatkan keterampilan berpikir kritis siswa, model ini bersifat interaktif dengan tahapan- tahapan dasar pembelajaran yang efektif, dinamis,dan efesien. 
Perkembangan TIK (Teknologi Informasi Komunikasi) yang pesat pada jaman ini, terbukti dengan prilaku masyarakat yang sangat suka menggunakan peralatan berteknologi tinggi. Semakin banyaknya masyarakat yang memiliki dan menggunakan perangakat mobile, membuka peluang penggunaan perangakat teknologi yang bergerak dalam dunia pendidikan, penggunaan perangakat bergerak (Mobile Device) dalam proses pembelajaran, kemudian dikenal sebagai Mobile Learning (M-Learning), yang diharapkan agar supaya siswa lebih aktif dikelas, meningkatkan daya tarik berlajar siswa dan mempermudah siswa untuk mengakses ilmu dengan memamfaatkan teknologi yang serba canggih.

Belajar menggunakan/ memanfaatkan mobile device atau handheld technology (misalnya, HP,PDas, iPod, Pocket PC) dikenal sebagai Mobile Learning atau M-Learning. M-Learning menggunakan/ memanfaatkan mobile device yang dapat dengan mudah dibawa dan digunakan dimana saja. Akibatnya M-Learning memungkinkan orang belajar dalam waktu dan tempat yang lebih fleksibel (Palupi,E.L.W., \& Patahuddin, S.M. (2010).

M-Learning lebih mengarah kepada kelas virtual ( Virtual Classroom). Materimateri dalam kegiatan pembelajaran tersebut kebanyakan dihantarkan melalui media internet, intranet, tape audio maupun video, satelit, telivisi interaktif, ataupun media penyimpanan seperti CD-ROM. Definisi ini menjelaskan bahwa tidak mutlak bahwa MLearning harus terhubung dengan internet. Namun, secara spesifik, definisi M- Learning adalah tergantung dari penyelenggara kegiatan M- Learning tersebut, cara penggunaan serta tujuan penggunaan. M-Learning yang digunakan dalam Penelitian ini memanaatkan learning mobile sistem Schoology. Dalam hal ini schoology membantu proses pembelajaran siswa untuk isian Lembar kerja siswa secara online.

Berdasarkan hasil wawancara yang dilakukan dengan salah satu guru matematika di SMP Negeri 4 Campaka, guru tersebut mengajar matematika di kelas 7. Hasil dari wawancara saya dengan guru tersebut dapat disimpulkan, model pembelajaran yang digunakan pada saat proses pembelajaran di SMP Negeri 4 Campaka adalah model pembelajaran ceramah dan diskusi, akan tetapi Menyesuaikan dengan tingkat kesulitan materi yang akan disampaikan. pada saat penyampaian materi dikelas VII menggunakan metode diskusi membuat siswa mengalami kesulitan untuk memahami konsep matematika, dan waktu penyampaianya juga berpegaruh penting karena jika mata pelajaran matematika disampaikan pada saat jam terakhir pembelajaran, siswa sudah tidak kondusif lagi. Hal ini terlihat jelas karena tidak adanya peningkatan hasil belajar siswa secara signifikan. Sehingga nilai murni siswa dalam satu semester terakhir hanya $20 \%$ siswa yang nilainya di 
atas KKM dan $80 \%$ siswa nilainya dibawah KKM. Permasalah lainya yang terjadi disekolah adalah guru cenderung jarang memberikan soal-soal/LKS sehingga kurangnya kegiatan yang melatih keterampilan berpikir kritis siswa.

Pada dasarnya kemampuan dan disposisi berpikir logis, kritis, dan kreatif adalah kemampuan dan disposisi esensial yang perlu dimiliki dan dikembangkan pada siswa yang belajar matematika (Sumarmo, u .dkk .2012). proses kemampuan siswa untuk mengidentifikasi asumsi yang digunakan, merumuskan poko-pokok permasalahan, menentukan akibat dari suatu ketentuan yang diambil, mendeteksi adanya bias berdasarkan padasudut pandang yang berbeda, mengungkap konsep, teorema atau didefinisikan yang digunakan, serta mengevaluasi argument yang relevan dalam menyelesaikan suatu masalah (Hidayar, W.2012).

Beberapa pakar, Ennis (1996) di dalam (Lestari, K. E., \& Yudhanegara, M. R. (2015)), mendefinisikan kemampuan berpikir dalam menyelesaikan masalah matematika yang melibatkan pengetahuan matematika, penalaran, dan pembuktian matematika Indicator kemampuan berpikir kritis yakni Memberikan penjelasan sederhana (elementary clarification), Membangun keterampilan dasar (basic support), Membuat simpulan (inference), Membuat penjelasan lanjut (advances clarification), Menemukan strategi dan taktik (strategi and tactics) untuk menyelesaikan maslah..

Dalam melaksanakan berpikir kritis, telibat diposisi berpikir yang dicirikan dengan: Bertanya secara jelas dan beralasan, berusaha memahami dengan baik, menggunakan sumber yang terpercaya, mempertimbangkan situasi secara keseluruhan, berusaha tetap mengacu dan relevan kepada masalah pokok, mencari berbagai alternatif, bersikap terbuka, berani mengambil posisi, bertindak cepat,bersikap atau berpandangan bahwa sesuatu adalah bagian dari keseluruhan yang kompleks, memanfaatkan cara berpikir orang lain yang kritis dan bersikap sensitif terhadap perasaan orang lain. Ennis (Sumarmo,dkk. 2012)

Kemampuan berpikir kritis matematis mutlak harus dimiliki dan dikembangkan oleh peserta didik dan juga harus diasah dari semenjak dini. Agar peserta didik dapat menentukan / mempertimbangkan secara hati-hati dan sengaja apakah menerima, menolak atau menunda penerimaan suatu informasi, dalam kemampuan berpikir kritis terdapat indicator-indikator dan ciri yang terlibat disposisi indikator kemampuan berpikir kritis.

Kemampuan berpikir kritis akan efektif dengan menggunakan pembelajaran. Salah satu model pembelajaran adalah inquiri. Inkuiri berasal dari bahasa Inggris Inqury yang dapat diartikan sebagai proses bertanya dan mencari tahu jawaban terhadap 
pertanyaan ilmiah yang diajukan. Strategi pembelajaran inkuiri adalah rangkaian kegiatan pembelajaran yang menekankan pada proses berpikir secara kritis dan analitis untuk mencari dan menemukan jawaban dari suatu masalah yang dipertanyakan. Proses pembelajaran dengan inkuiri mengikuti (Damayanti,D.S . 2013) langkah-langkah:

\section{Tabel 1. Proses Pembelajaran Inkuiri}

\section{Fase}

\section{Langkah-langkah}

1 Orientasi. Orientasi merupakan langkah yang dilakukan guru untuk mengkondisikan agar peserta didik siap melaksanakan proses pembelajaran.

2 Merumuskan masalah. Merumuskan masalah merupakan langkah membawa peserta didik pada suatu persoalan.

3 Mengajukan hipotesis. Hipotesis merupakan jawaban sementara dari suatu permasalahan yang sedang dikaji.

4 Mengumpulkan data Tahapan ini yaitu aktivitas menjaring informasi yang dibutuhkan untuk menguji hipotesis yang diajukan. Dalam inkuiri terbimbing menjaring inforasi dilakukan bersama-sama antara guru dan peserta didik

5 Menguji hipotesis. Menguji hipotesis adalah proses menetukan jawaban yang dianggap diterima sesuai dengan data dan informasi yang diperoleh berdasarkan pengumpulan data.

6 Merumuskan kesimpulan .Merumuskan masalah yaitu proses mendiskripsikan temuan yang diperoleh berdasarkan hasil pengujian hipotesis

Pembelajaran inkuiri terbimbing (Guided inquiry) yaitu suatu model pembelajaran inkuiri yang dalam pelaksanaannya guru menyediakan bimbingan atau petunjuk cukup luas kepada peserta didik, Piaget mengemukakan bahwa model inkuiri adalah model yang mempersiapkan peserta didik pada situasi untuk melakukan eksperimen sendiri secara luas agar melihat apa yang terjadi, ingin mencari jawaban sendiri serta menghubungkan penemuan yang satu dengan penemuan yang lain, kemudian membandingkan apa yang ditemukan dengan yang ditemukan peserta didik lainnya dalam (Damayanti,D.S . 2013).

Salah satu tujuan penelitian ini untuk menjadi alternatif dari permasalahan yang kita bahas, dengan adanya pengembangan lembar kerja siswa (LKS) dengan pendekatan inkuiri terbimbing berbasis mobile learning dapat mengoptimalkan kemampuan berpikir kritis matematis dalam pembelajaran matematika. 


\section{METODOLOGI PENELITIAN}

Penelitian ini menggunakan metode penelitian pengembangan (Research and development). Menurut Suetarno, Penelitian pengembangan adalah upaya untuk mengembangkan dan menghasilkan suatu produk berupa materi, media, alat atau strategi pembelajaran, digunakan untuk mengatasi pembelajaran di kelas/ laboratorium, dan bukan untuk uji teori. Adapun tahap yang dilakukan mengacu pada model pengembangan ADDIE yang dikembangakan oleh Dick dan Carey (1987) didalam (Alkarimah,Annisa. Rusdi. Fachruddin,M. 2017), adapun produk yang akan dikembangkan yaitu Lembar kerja siswa (LKS) berbasis Mobile Learning. Prosedur dalam penelitian ini dilaksanakan seperti tabel berikut.

\section{Tabel 2. Keterangan Prosedur Metode ADDIE}

\begin{tabular}{lll}
\hline No & Prosedur & Keterangan \\
\hline $\mathbf{1}$ & Analisis & $\begin{array}{l}\text { Tahap analisis dalam hal ini menganalisis siswa, analisis kurikulum } \\
\text { dan analisis materi uji yang sesuai dengan kurikulum 2013. Analisis } \\
\text { tingkat kemampuan dan karakterisitik sasaran penggunaan }\end{array}$ \\
\hline $\mathbf{2}$ & Design & $\begin{array}{l}\text { Tahapan ini merupakan proses perancangan butir-butir materi yang } \\
\text { akan disajikan, penyusunan materi, penyusunan alur penyampaian } \\
\text { materi, pembuatan LKS dan mengumpulkan bahan-bahan yang } \\
\text { dibutuhkan dalam pengembangan LKS }\end{array}$ \\
\hline $\mathbf{3}$ & Development & Pembuatan LKS berbasis mobile learning \\
\hline $\mathbf{4}$ & Implementation & $\begin{array}{l}\text { Penilaian oleh ahli bahan ajar LKS, ahli materi, dan praktisi lapangan } \\
\text { serta pelaksanaan uji coba terbatas }\end{array}$ \\
\hline $\mathbf{5}$ & Evaluation & $\begin{array}{l}\text { Penilaian terhadap LKS yang dikembangkan, dilakukan selama empat } \\
\text { tahap sebelumnya }\end{array}$ \\
\hline
\end{tabular}

Subjek penelitian dilaksanakan di SMP Negeri 4 Campaka kelas VII pada semester genap tahun ajaran 2018/2019. Metode pengumpulan data penelitian menggunakan angket, observasi, wawancara dan tes. Adapun. Teknik analisi data yang digunakan dalam penelitian ini adalah Uji Validasi, Uji Reliabilitas, Analisis Hasil Telaah Lembar Kerja Siswa (LKS), Respon Peserta didik Menghitung skor rata-rata dari setiap komponen, Analisis Lembar Kemampuan Berpikir Kritis dilihat dari skor yang diperoleh Kriteria Ketuntasan Minimal (KKM). 


\section{HASIL DAN PEMBAHASAN}

\section{Analisis}

Pada tahap anallisis bahan ajar LKS dalam pembelajaran matematika pada materi geometri bangun datar dikembangkan berdasarkan standar kompetensi lulusan yang diatur dalam Lampiran Peraturan Menteri Pendidikan Dan Kebudayaan Nomor 20 Tahun 2016 Tentang Standar Kompetensi Lulusan Pendidikan Dasar Dan Menengah yakni

1. Sikap : Memiliki perilaku yang mencerminkan sikap: beriman dan bertakwa kepada Tuhan YME, berkarakter, jujur, dan peduli, bertanggungjawab, pembelajar sejati sepanjang hayat, dan sehat jasmani dan rohani sesuai dengan perkembangan anak di lingkungan keluarga, sekolah, masyarakat dan lingkungan alam sekitar, bangsa, negara, dan kawasan regional.

2. Pengatahuan: Memiliki pengetahuan faktual, konseptual, prosedural, dan metakognitif pada tingkat teknis dan spesifik sederhana berkenaan dengan ilmu pengetahuan, teknologi, seni, dan budaya. dalam konteks diri sendiri, keluarga, sekolah, masyarakat dan lingkungan alam sekitar, bangsa, negara, dan kawasan regional.

3. Keterampilan : Memiliki keterampilan berpikir dan bertindak: kreatif, produktif, kritis, mandiri, kolaboratif, dan komunikatif melalui pendekatan ilmiah sesuai dengan yang dipelajari di satuan pendidikan dan sumber lain secara mandiri

Setelah menyesuaikan dengan standar kompetensi lulusan kemudian disesuaikan dengan tingkat pendidikan sekolah menengah yang mencakup kompetensi dasar materi geometri berdasarkan aspek sikap, pengetahuan dan keterampilan. Selanjutnya, disesuaikan dengan karakteristik nilai budaya campaka. Bahan ajar dan pembelajaran geometri yang dikembangkan dari silabus terdiri dari segiempat (persegi, persegi panjang, belah ketupat, jajargenjang,trapesium,dan layan-glayang) dan segitiga.

\section{Design}

Tahapan ini materi yang disajikan disesuaikan dengan rencana pelaksanaan pembelajaran (RPP) sesuai dengan kompetensi dasar pada silabus sebagai berikut:

\section{Tabel 3. Kompetensi Dasar Geometri}

\section{Kompetensi Dasar}

Pengetahuan Keterampilan
3.11. Mengaitkan rumus keliling dan luas
4.11 Menyelesaikan masalah
untuk berbagai jenis segiempat
konstektual yang berkaitan dengan
(persegi, persegi panjang, belah
luas dan keliling segiempat (persegi, 
ketupat, jajargenjang,trapesium,dan

layan-glayang) dan segitiga. persegi panjang, belah ketupat,

jajargenjang,trapesium,dan layan-

glayang) dan segitiga.

Tahapan penusunan materi direncanakan empat pertemuan dengan tahapan pertama penyampaian karakteristik dan keliling segiempat, luas segiempat, karakteristik dan keliling segitiga serta luas segitiga. Pembuatan LKS disesuaikan dengan petemuan yakni pertemuan pertama karakteristik dan keliling segiempat terdiri dari enam LKS, petemuan kedua luas segiempat terdiri dari enam LKS, pertemuan ketiga karakteristik dan keliling segitiga terdiri dari tiga LKS dan pertemuan keempat terdiri dari 3 LKS. Seluruluh LKS terdiri dari 18 LKS. Bahan yang dikumpulkan dalam mengembangkan LKS diataranya dari buku paket siswa dan guru edisi revisi 2017, internet dan sumber lainnya.

\section{Development}

Lembar Kegiatan siswa (Student Work Sheet) adalah lembaran-lembaran berisi tugas yang harus dikerjakan perseta didik. Lembar kegiatan siswa yang dikembangkan memuat Judul, materi pokok, kelas/semseter, tujuan pembelajaran, identitas kelompok, petujunjuk penggunaan LKS, tugas yang dikerjakan berupa masalah inquiri dan kesimpulan.

Berikut tampilan LKS yang dikembangkan dengan mobile learning dengan bantuan google form:
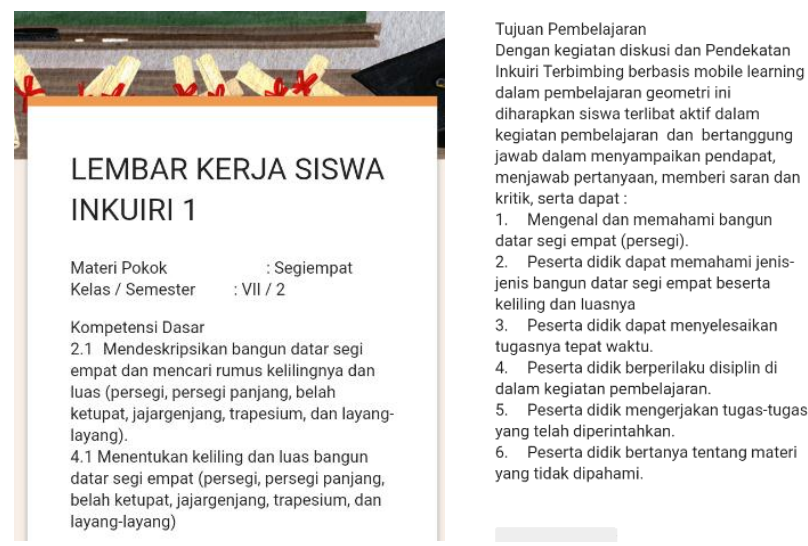

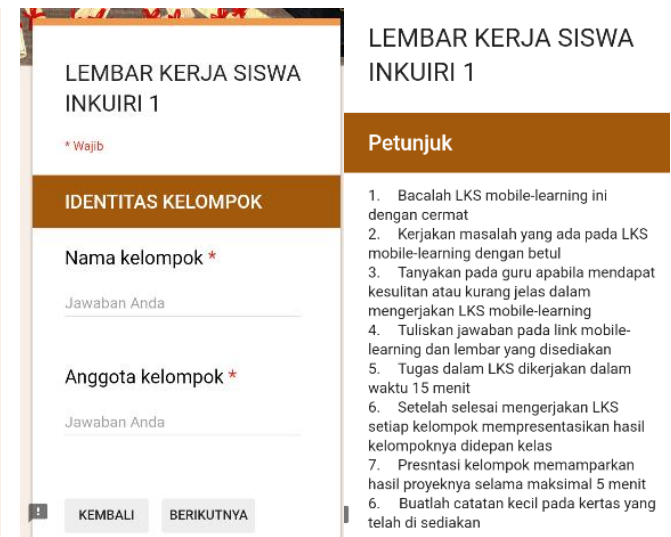

\section{Gambar 1. Tampilan LKS (Judul, Kompetensi Dasar, Tujuan Pembelajaran, Identitas Kelompok, dan Petunjuk)}


Kemudian tampilan tugas inquri dimana siswa menemukan konsep segiempat berupa masalah sesuai dengan kehidupan sehari-hari sebagai berikut:

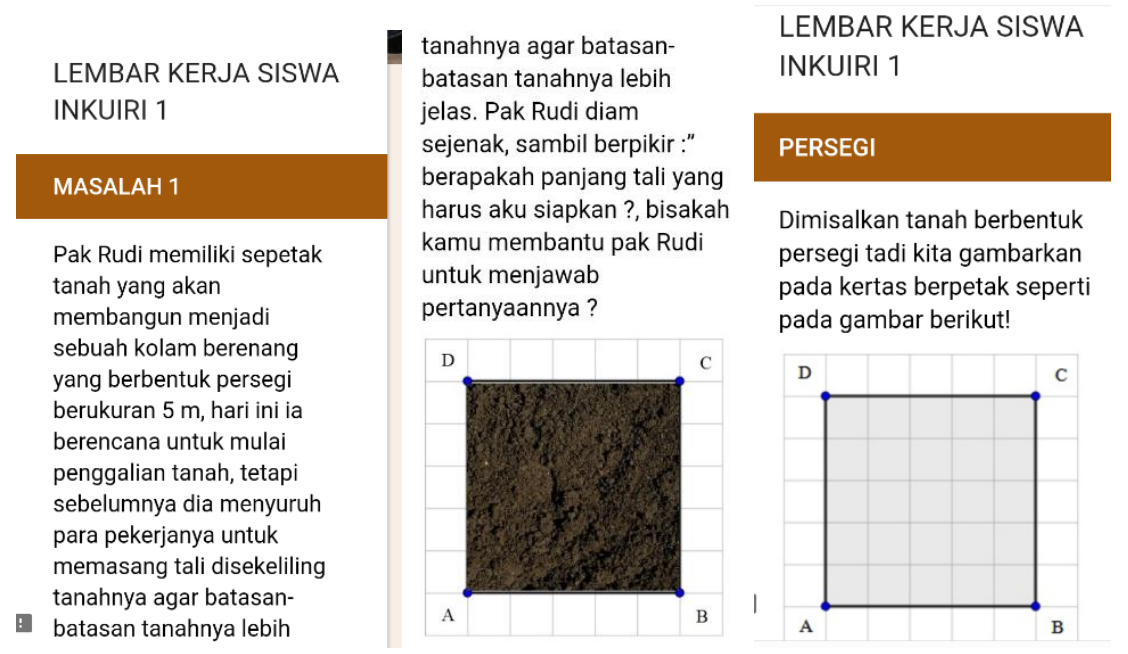

Gambar 2. Tampilan LKS (Uraian Masalah Inquiry)

Dari permasalahan tersebut siswa dituntut untuk memecakan masalah dan kemudian menemukan konsep matematika dengan bimbingan guru. Berikut tampilan pertanyaan untuk siswa yang membantu memeahkan dan menemukan konsep matematika:

1. Coba perhatikan gambar
diatas! Menurut kalian
berbentuk apakah sepetak
tanah diatas?
Jawaban Anda
2. Apa yang kalian ketahui
mengenai sifat dari persegi?
Jawaban Anda
3. Persegi adalah bangun
yang keempat sisinya?
Jawaban Anda

Berapa panjang sisi AB, BC,
CD, DA pada gambar diatas !
Jawaban Anda
Dilihat dari panjang sisi AB,
BC, CD, DA jadi rumus
keliling persegi adalah ....
Jawaban Anda
Berapakah panjang tali yang
diperlukan pak Rudi?
Jawaban Anda

Berapa panjang sisi $A B, B C$, Hani mempunyai tugas mencari keliling dan
sisi pada sebuah persegi dari guru
disekolahnya. Bisakah kalian membantu
Hani dalam mengerjakan tugas matematika !

Apabila diketahui panjang sisi persegi $11 \mathrm{~cm}$ maka keliling persegi adalah?

Jawaban Anda

\section{Apabila diketahui keliling persegi $36 \mathrm{~cm}$ maka panjang sisi persegi adalah?}

Jawaban Anda

\section{Gambar 3. Tampilan (Uraian Pertanyaan Inqury)}

Setelah siswa memahkan masalah kemudian siswa diberi kesempatan untuk menyimpulkan seperti tampilan berikut: 


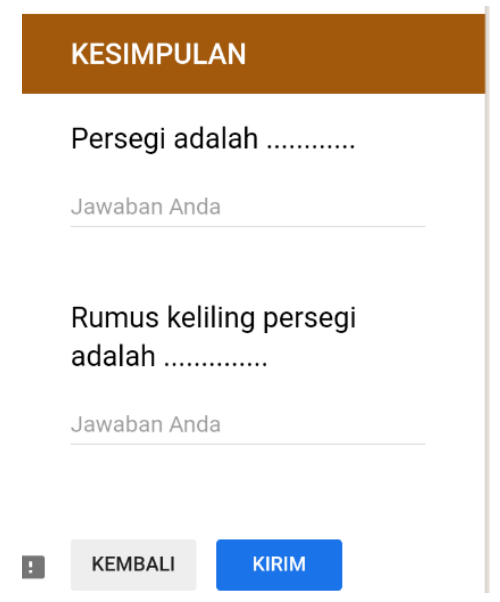

\section{Gambar 4. Tampilan (Kesimpulan)}

Semua topik segiempat dan segitiga dikembangkan dengan mengikuti alur tersebut. Kemudian link dari google form dinput kedalam akun schoology. Kode akses akun schoology diserbarkan pada siswa dan siswa dengan mudah mengakses akun tersebut menggunakan mobile learning pada saat pembelajaran.

\section{Implementation}

Kevalidasiaan LKS dalam pelaksanaan pembelajaran matematika menggunakan model mobile learning yang bertujuan melatih keterampilan berpikir kritis siswa sangat penting untuk mengukur sejauh mana kelayakan LKS tersebut diaplikasikan kepada peserta didik, banyak hal-hal yang dipertimbangkan dalam pembuatan Lembar Kerja Siswa (LKS) berbasis E-Learning agar bisa mengoptimalkan kemampuan berpikir kritis matematis dan nilai karakter budaya Campaka.

Hasil Penilaian Lembar Validasi LKS terdapat 8 Validator yang menilai ke Validasian Suatu LKS. Penilaian dari Validator tersebut sifatnya wajib untuk membuat sebuah rancangan Lembar Kerja Siswa (LKS) yang baik dan benar agar bisa di aplikasikan kepada siswa dan tercapainya tujuan suatu pembelajaran.

Validator yang menilai ke Validasian Suatu LKS bisa oleh Dosen, Guru, Mahasiswa, Mahasiswi, Siswa. Validator harus dari berbagai macam kalangan, karena pandangan, pola-pikir, penilian setiap kalangan itu berbeda. Hal tersebut merupakan nilai penting untuk menghasilkan LKS yang memiliki kualitas baik.

Dalam penilaian Lembar Kerja Siswa (LKS), Validator di arahkan untuk mengisi Lembar Validasi LKS yang telah di sediakan. Dengan bertujuan untuk mengukur 
kevalidsian LKS dalam pelaksanaan pembelajaran matematika menggunakan model mlearning berbasis penemuan, Validator dapat memberikan penilaian dengan memberikan cek $(\sqrt{ })$ pada poin yang tersedia. Makna point validitas adalah 1 (tidak baik): 2 (kurang baik): 3 (cukup): 4 (baik): 5 (sangat baik).

\section{Tabel 4. Identitas LKS}

\begin{tabular}{|c|c|c|c|c|c|}
\hline \multirow{2}{*}{ Indikator penilaian } & \multicolumn{5}{|c|}{ Nilai yang diberikan } \\
\hline & 1 & 2 & 3 & 4 & 5 \\
\hline Kesesuaian topik LKS dengan KI dan KD & 0 & 0 & 1 & 2 & 5 \\
\hline Kesesuaian Alokasi Waktu & 0 & 1 & 1 & 3 & 3 \\
\hline Mencantumkan tujuan pembelajaran & 0 & 0 & 1 & 2 & 5 \\
\hline $\begin{array}{l}\text { 4. Mencantumkan petunjuk kegiatan dalam } \\
\text { LKS }\end{array}$ & 0 & 0 & 1 & 4 & 3 \\
\hline Jumlah & 0 & 1 & 4 & 11 & 16 \\
\hline Modus & \multicolumn{5}{|c|}{5 (Sangat Baik) } \\
\hline
\end{tabular}

Dari Tabel 4. Dapat dilihat Jumlah Penilaian LKS berbasis Mobile Learning yang diberikan dengan Indikator Identitas LKS adalah 1 (Kurang baik), 4 (Cukup), 11 (Baik), 16 (Sangat baik). Berdasarkan data penilaian para ahli maka modus dari indikator penilain identitas LKS adalah sangat baik.

Tabel 5. Syarat Teknik/Desain LKS

\begin{tabular}{|c|c|c|c|c|c|c|}
\hline \multirow{2}{*}{\multicolumn{2}{|c|}{ Indikator penilaian }} & \multicolumn{5}{|c|}{ Nilai yang diberikan } \\
\hline & & 1 & 2 & 3 & 4 & 5 \\
\hline 1. & Kesesuaian cover dengan topik LKS & 0 & 0 & 0 & 6 & 2 \\
\hline 2. & Kesesuaian tulisan dan huruf & 0 & 0 & 0 & 6 & 2 \\
\hline 3. & Kesesuaian tata letak dengan isi LKS & 0 & 0 & 0 & 5 & 3 \\
\hline 4. & $\begin{array}{l}\text { Tampilan warna dan gambar menarik } \\
\text { perhatian siswa dan meningkatkan } \\
\text { motivasi belajar }\end{array}$ & 0 & 0 & 0 & 6 & 2 \\
\hline & Jumlah & 0 & 0 & 0 & 23 & 9 \\
\hline & Modus & \multicolumn{5}{|c|}{4 ( baik) } \\
\hline
\end{tabular}

Dari Tabel 5. Dapat dilihat Jumlah Penilaian LKS berbasis Mobile Learning yang diberikan dengan Indikator Syarat Teknik/Desain LKS adalah 23 (Baik), 9 (Sangat baik) Berdasarkan data penilaian para ahli maka modus dari indikator penilain desaian LKS adalah baik. 
Tabel 6. Syarat Kontruksi (Kebahasaan)

\begin{tabular}{cllllll}
\hline & \multicolumn{1}{c}{ Indikator penilaian } & \multicolumn{5}{c}{ Nilai yang diberikan } \\
\cline { 2 - 7 } & 1 & 2 & 3 & 4 & 5 \\
\hline 1. & $\begin{array}{l}\text { Kalimat yang digunakan jelas, operasional } \\
\text { dan tidak menimbulkan makna ganda }\end{array}$ & 0 & 0 & 0 & 4 & 3 \\
\hline $2 . \quad \begin{array}{l}\text { Bahasa yang digunakan mudah dimengerti } \\
\text { oleh siswa }\end{array}$ & 0 & 0 & 0 & 7 & 0 \\
\hline $3 . \quad \begin{array}{l}\text { Bahasa yang digunakan pada LKS mengajak } \\
\text { siswa untuk interaktif }\end{array}$ & 0 & 0 & 0 & 7 & 0 \\
\hline & Jumlah & 0 & 0 & 0 & 18 & 3 \\
\hline & Modus & & \multicolumn{5}{c}{4 (Baik) } \\
\hline
\end{tabular}

Dari Tabel 6. Dapat dilihat Jumlah Penilaian LKS berbasis Mobile Learning yang diberikan dengan Indikator Syarat Kontruksi (Kebahasaan) adalah 18 (Baik), 3 (Sangat baik). Berdasarkan data penilaian para ahli maka modus dari indikator penilain Syarat Kontruksi (Kebahasaan) adalah baik.

Tabel 7. Penilaian Isi

\begin{tabular}{|c|c|c|c|c|c|}
\hline \multirow[t]{2}{*}{ Indikator penilaian } & \multicolumn{5}{|c|}{ Nilai yang diberikan } \\
\hline & 1 & 2 & 3 & 4 & 5 \\
\hline 1. Memenuhi syarat didaktik & 0 & 0 & 1 & 4 & 2 \\
\hline $\begin{array}{l}\text { 2. Materi yang disampaikan sesuai dengan } \\
\text { konsep }\end{array}$ & 0 & 0 & 0 & 7 & 0 \\
\hline $\begin{array}{l}\text { 3. Materi sesuai dengan indikator dan tujuan } \\
\text { pembelajaran }\end{array}$ & 0 & 0 & 0 & 7 & 0 \\
\hline 4. Kesesuaian urutan materi & 0 & 0 & 1 & 3 & 3 \\
\hline Jumlah & 0 & 0 & 2 & 21 & 5 \\
\hline Modus & \multicolumn{5}{|c|}{4 (Baik) } \\
\hline
\end{tabular}

Dari Tabel 5. Dapat dilihat Jumlah Penilaian LKS berbasis Mobile Learning yang diberikan dengan Indikator Isi LKS adalah 2 (Cukup), 21 (Baik), 5 (Sangat baik). Berdasarkan data penilaian para ahli maka modus dari indikator penilain isi LKS adalah baik. 
Tabel 8. Karakteristik LKS Berbasis Mobile Learning

\begin{tabular}{|c|c|c|c|c|c|}
\hline \multirow[t]{2}{*}{ Indikator penilaian } & \multicolumn{5}{|c|}{ Nilai yang diberikan } \\
\hline & 1 & 2 & 3 & 4 & 5 \\
\hline $\begin{array}{l}\text { 1. LKS membimbing siswa untuk membuat } \\
\text { pertanyaan dan rumusan masalah }\end{array}$ & 0 & 0 & 1 & 5 & 1 \\
\hline $\begin{array}{l}\text { 2. LKS membimbing siswa untuk berfikir } \\
\text { kreatif dan kritis }\end{array}$ & 0 & 0 & 0 & 7 & 0 \\
\hline $\begin{array}{l}\text { 3. LKS membimbing siswa untuk membuat } \\
\text { rancangan Pelaksanaan Kegiatan }\end{array}$ & 0 & 0 & 0 & 6 & 1 \\
\hline $\begin{array}{l}\text { 4. LKS Membimbing siswa untuk } \\
\text { Mengumpulkan Data Melalui Pengamatan }\end{array}$ & 0 & 0 & 1 & 5 & 1 \\
\hline $\begin{array}{l}\text { 5. LKS membimbing siswa untuk Mengelola } \\
\text { data }\end{array}$ & 0 & 0 & 3 & 2 & 2 \\
\hline $\begin{array}{l}\text { 6. LKS membimbing siswa untuk melakukan } \\
\text { pembuktian data dan menarik kesimpulan }\end{array}$ & 0 & 0 & 1 & 4 & 2 \\
\hline $\begin{array}{l}\text { 7. LKS membimbing siswa untuk bersikap } \\
\text { someah kepada teman dan lingkungan }\end{array}$ & 0 & 0 & 0 & 7 & 0 \\
\hline 8. LKS melatih tanginas siswa untuk belajar & 0 & 0 & 1 & 3 & 3 \\
\hline $\begin{array}{l}\text { 9. LKS melatih siswa untuk belajar } \\
\text { berkelompok secara sauyunan }\end{array}$ & 0 & 0 & 0 & 5 & 2 \\
\hline 10. LKS melatih disiplin siswa untuk belajar & 0 & 0 & 0 & 5 & 2 \\
\hline $\begin{array}{l}\text { 11. LKS memunculkan nilai karakter siswa } \\
\text { (tanginas, sauuyunan, someah) dalam } \\
\text { pembelajaran }\end{array}$ & 0 & 0 & 1 & 4 & 2 \\
\hline Jumlah & 0 & 0 & 8 & 53 & 16 \\
\hline Modus & & & & & \\
\hline
\end{tabular}

Dari Tabel 8. Dapat dilihat Jumlah Penilaian LKS berbasis Mobile Learning yang diberikan dengan Indikator Karakteristik LKS Berbasis Mobile Learning adalah 8 (Cukup), 53 (Baik), 16 (Sangat baik). Berdasarkan data penilaian para ahli maka modus dari indikator penilain Karakteristik LKS Berbasis Mobile Learning adalah baik.

Secara umum simpulan dari penilain LKS dari beberapa validator yakni sebagai berikut: 


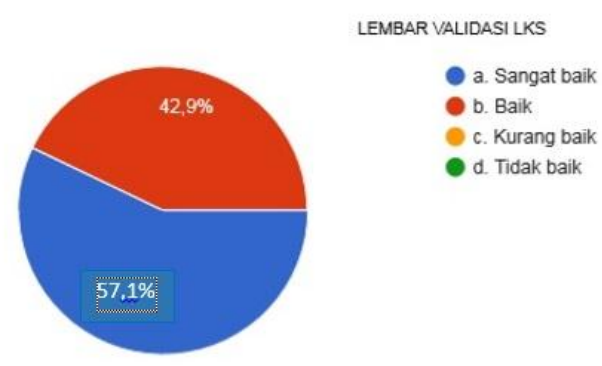

\section{Gambar 3. Diagram Penilaian Secara Umum Format LKS}

Dari hasil akumulasi keseluruhan penilaian validator secara umum format LKS 42,9 \%, penilaiannya Baik dan dan 57,1\% Memiliki penilaian Sangat Baik. Akhir dari penilain validator untuk kelayakan LKS diberikan pada siswa SMP yaki sebagai berikut:

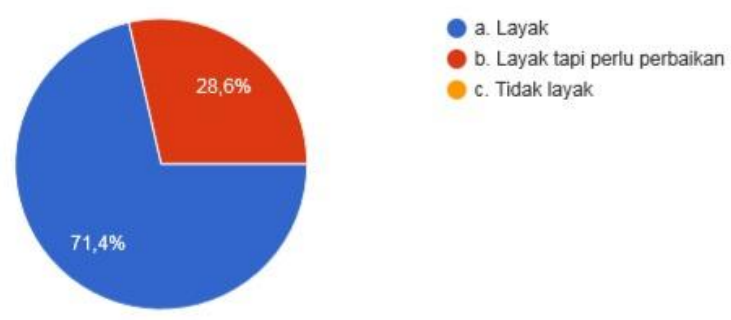

\section{Gambar 4. Diagram Penilaian Secara Keseluruhan LKS}

Dari hasil penilian akumulasi keseluruhan penilaian Validator mengenai Kelayakan LKS dapat disimpulkan $28,6 \%$ LKS layak digunakan tetapi perlu perbaikan dan $71,4 \%$ LKS layak digunakan.

\section{Evaluation}

Setelah LKS tersebut dinilai layak oleh validator maka digunakan dalam pembelajaran di kelas. Berdasarkan hasil pembelajaran menggunakan LKS berbasis mobile learning maka didapatkan data untuk dievaluasi yakni

\section{Pengoptimalan Kemampuan Berpikir Kritis Terhadap Lks Berbasis Mobile Learning}

Pengoptimalan kemampuan berpikir kritis berdasarkan tes yang diisi oleh siswa sebagai berikut: 
Tabel 9. Diperoleh Capaian Kemampuan Berpikir Kritis

\begin{tabular}{lllllll}
\hline Jumlah & Besar & Nilai & rata- & $\begin{array}{l}\text { Banyaknya } \\
\text { Mencapai KKM }\end{array}$ & Siswa & Presentase \\
Siswa & KKM & rata & 13 & $62 \%$ \\
\hline $\mathbf{2 1}$ & 70 & 71,08 & & & \\
\hline
\end{tabular}

Dalam Presentase data Kemampuan Berpikir Kritis siswa dengan standar KKM 70 untuk mata pelajaran Matematika di SMP Negeri 4 Campaka dengan Lembar Kerja Siswa (LKS) Berbasis Mobile Learning dapat disimpulkan 62\% siswa memiliki Nilai diatas KKM dan 38\% Siswa memiliki nilai dibawah KKM, maka penggunaan LKS dapat mengoptimalkan sebgian besar kemampuan berpikir kritis siswa.

\section{Respon Siswa Terhadap Lks Berbasis Mobile Learning}

Analisis data hasil kuesioner sikap siswa terhadap LKS berbasis Mobile Learning disajikan pada tabel berikut :

Tabel 10. Analisis data hasil sikap siswa terhadap LKS berbasis Mobile Learning

\begin{tabular}{ccc}
\hline \multicolumn{2}{c}{ Frekuesi dan } & Keterangan \\
\multicolumn{2}{c}{ Presentase } & \\
\cline { 1 - 2 } Sikap & Sikap & \\
Positif & Negatif & \\
\hline $\mathbf{5 6 , 5 2 \%}$ & $29,95 \%$ & Pada Umumnya Positif \\
\hline
\end{tabular}

Dari Tabel 4.2 dapat dilihat bahwa sebagian besar pernyataan ditanggapi siswa dengan positif dapat dilihat dari nilai rata-rata persentase sikap siwa pada umumnya positif terhadap LKS berbasis mobile learning.

\section{KESIMPULAN}

Berdasarkan hasil penelittian menunjukan bahawa pengembangan lembar kerja siswa (LKS) dengan pendekatan inkuiri terbimbing berbasis mobile learning dari hasil validator baik dan layak serta dapat mengoptimalkan kemampuan berpikir kritis matematis disertai sikap positif siswa. 


\section{REFERENSI}

Alkarimah, dkk. (2017). Efektifitas Media Pembelajaran Matematika Menggunakan Software Animasi Berbasis Multimedia Interaktif Model Tutorial Pada Materi Garis Dan Sudut untuk Siswa SMP/MTS Kelas VII. Jurnal Penelitian Pembelajaran Matematika Sekolah (JP2MS),Vol.1, No.1.

Damayanti, D. (2013) Pengembangan Lembar Kerja Siswa (LKS) Dengan Pendeketan Inkuiri Terbimbing Untuk Mengoptimalkan Kemampuan Berpikir Kritis Peserta didik pada Materi Listrik Dinamis SMA Negeri 3 Purworejo Kelas X tahun pelajaran 2012/2013. RADIASI: Jurnal Berkala Pendidikan Fisika, 3(1) 58-62.

Hidayar, W. (2012). Meningkatkan Kemampuan Matematik Siswa SMA melalui Pembelajaran Kooperatif Think-Talk-Write (TTW). Seminar Nasional Penelitian, Pendidikan dan Penerapan MIPA.

Lestari, K. E., \& Yudhanegara, M. R. (2015). Penelitian Pendidikan Matematika. Bandung: Refika Aditama.

Palupi, E.L.W., \& Patahuddin, S.M. (2010). Pengembangan Mathematics Moble Learning Aplication (MMLA)- Sistem Persamaan Linear Dua Variable (Spldv) untuk siswa SMP kelas 8 .

Sumarmo, U., Hidayat, W., Zukarnaen, R., Hamidah, M., \& Saringsih, R.(2012). Kemampuan dan Disposisi Berpikir Logis, Kritis, dan Kreatif Matematik (Eksperimen terhadap Siswa SMA Menggunakan Pembelajaran Berbasis Masalah dan Strategi Think- Talk-Write). Jurnal Pengajaran MIPA,17(1),17-33 